POLSKA AKADEMIA NAUK-ZAKEAD BADANIA SSAKOW

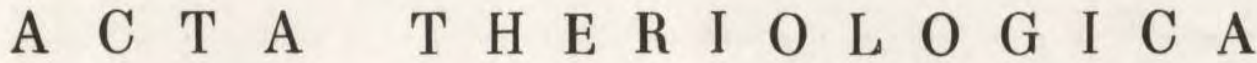

VOL. IX, 14: 193-215.

\section{Variation in the Weight of the Brown Adipose Tissue of Sorex araneus Linnaeus, 1758}

\section{Zmienność wagowa tkanki thuszczowej brunatnej Sorex araneus Linna e us, 1758}

[With 4 Tables \& 6 Figs.]

I. Introduction

II. Material and methods

III. Seasonal variation in the weight of the brown adipose tissue of the Common shrew

1. Females

3. Differences in the course taken by curve of variation in different years

a. young animals . . . . . . . . . . . 202

b. old adults . . . . . . . . 203

IV. Ratio of the weight of brown adipose tissue to body weight . . . . 204

v. Discussion . . . . . . . . . . . . . 207

VI. Conclusions . . . . . . . . . . . . . . . . 211

References . . . . . . . . . . . . . . . . 212

Streszczenie . . . . . . . . . . . . . . . . . 214

\section{INTRODUCTION}

Research on the seasonal changes taking place in the organism of shrews (Sorex araneus $\mathrm{L}$ in nae u s, 1758) was initiated by the discovery of the seasonal variation in the height of the skull (D e h n e l, 1949). Investigation was made ( $\mathrm{P} \mathrm{u} \mathrm{ce} \mathrm{k,} \mathrm{1956;}$ 1957) of the mechanism of this phenomenon, today known as the Dehnel phenomenon, and this in turn drew attention to the seasonal variation in the volume and weight of the brain (C a boń, 1956; Bielak \& P ucek, 1960). Seasonal variation in the skull were confirmed by examination of material from other parts of the living area of different species of the genus Sorex ( $\mathrm{S} \mathrm{h} \mathrm{ubarth}, 1958 ; \mathrm{Cr}$ ow croft \& Ingles, 1959; Pu cek, 1963).

Seasonal variation were also observed in the weight and length of the shrew's body (D e h n e 1, 1949). 
Investigations were also made of the variation in certain of the internal organs of $S$. araneus, for instance the morphohistological changes in the thymus gland during the life cycle of these animals ( $\mathrm{B} \mathrm{a} \mathrm{z} \mathrm{a} \mathrm{n,} \mathrm{1952),} \mathrm{the} \mathrm{histomorphological} \mathrm{variation}$ in the thyroid gland, also examined over the life cycle (D z i e r z y kraj - R og a l$\mathrm{ska}, 1952$ ), variation in the parathyroid glands (Dzierżykraj-Rogalska. 1956) and variation in the weight of the salivary glands ( $\mathrm{B} \mathrm{u} \mathrm{chalcz} \mathrm{ck}, 1961$ ).

The present study is intended to give a picture of the variation in the browr. adipose tissue ${ }^{1}$ ) depending on the season and also on the age of the animals. It is a well-known fact that the shrew does not go into hibernation for the winter. Brown adipose tissue attains considerable dimensions in this species and occurs both in young and in old adult animals, in the winter and at different times of the year.

Brown adipose tissue differs distinctly, both macroscopically and in its microscopical structure, from ordinary adipose tissue (Wertheimer' \& S h a piro 1948; F a w cett, 1952; Men s chik, 1953; Johan s on, 1959; K a y s e r, 1961).

It was at first assumed that it occurs only in animals which go into hibernation for the winter, in which it was initially found Gressner, 1551, cited acc. to Johans on (1959); Vels ch, 1670 - cited acc. to Con in x - Girardet (1927) $B$ a r k ov, who termed the $B A T$ which he found in a sleeping hedgehog the hibernating gland - cited after $\mathrm{Ka} \mathrm{labukhov}$ (1956). In later investigations it was found that this tissue may not even occur at all in hibernating animals ( $\mathrm{C}$ o n in $\mathrm{x}$ - Girardet, 1927), whereas, for instance, it exists in its embryonic form in mice and rats throughout their entire life (Wertheimer \& Shapiro, 1948) and in the rabbit in embryos (K a rolew ic z, 1953),

Certain research workers, e.g. B o erner - Patzelt (1957), have, however, found by means of histological examination that the "hibernating glands" of mammals which sleep through the winter are not identical with apparently similar formations occurring in mammals which do not sleep during the winter - which would throw a certain light on any differences becoming evident during the course of their variations.

A detailed description of the more important stages of research on BAT is given by R a smussen, 1923 (cited after J o'h a n s on, 1959).

The function of $B A T$ in the organism is, properly speaking, unknown up to the present. Ka y ser (1961) emphasises that it is an unquestionable fact that the function of "brown fat" is that of a fat reserve, referring to the research carried out by Valentin (1887) on losses in body weight, weight of ordinary and brown adipose tissue in Arctomys marmota (Linnaeus, 1768) during its winter sleep. $\mathrm{Ka} \mathrm{la} \mathrm{bukhov}(1956)$ is of the same opinion. The reserves contained in BAT may be utilised not during winter sleep but after the animal awakens, during the period of the oestrus which ensues, as has been estabished by Ka r ole wi c z (1953) in the case of the hedgehog.

Taking as a basis the fact that BAT is often well developed in animals which do not go into hibernation for the winter, and may not occur at all in animals which do hibernate, $\mathrm{K}$ a y s er (1961) denies that it should be attributed a specific role in the genesis of winter sleep and states that this special reserve tissue is subject to cyclical seasonal variations dependent in turn on the cycle of hypophysis.

1) Numerous synonyms have been used for this tissue, such as: primitive fat organ, fat gland, hibernating gland, interscapular gland, lipcid gland, cholesterol gland, glandula insularis cervicalis, multilocular adipose tissue (S e ly e \& Timi$\mathrm{ras}, 1949)$, amongst which the most generally used is the term, after Karolewi c z (1953), brown adipose tissue (BAT). 
Certain authors consider that this tissue stores not only fat but also glycogen and in particular vitamin C. Pta k (1963) took into consideration the possibility of this tissue fulfilling both a storage function and that of synthesis of corticoids. $\mathrm{He}$ also states that at times the morphological picture of the tissue would seem to suggest that it is capable of taking over the function of the adrenal glands in the event of the hypofunction of the latter. These phenomena were examined by Ratsimamang a et al. (1958) who demonstrated, inter alia, that a factor occurs in $B A T$ which has a certain analogy with a similar factor in the adrenal glands, which enables rats from which the adrenal glands have been excised to prolong their life while they are kept in a low temperature.

Smalley \& Dryer (1963), referring to numerous authors, suggest that BAT, owing to the production of heat, may play an important part during the time that bats wake from their winter sleep. According to $\mathrm{S} \mathrm{mith} \mathrm{(cited} \mathrm{after} \mathrm{Sm}$ alle $\mathrm{y}$ \& Dryer, 1963) BAT fulfills these functions in rodents (rats), in which it forms a source of warmth during the animals' adaptation to cold. S mith \& Hock (1963) found that BAT plays a thermogenetic part in sleeping Marmota flaviventris (A ud. \& B a ch., 1841). It is clear from the research carried out by $\mathrm{S}$ el y e \& $\mathrm{T}$ imiras (1949) and S u omalainen \& Herlevi (1951) that BAT plays an active part in conditions of stress (e.g. the stress of cold) of the organism.

Investigations of $B A T$ as an organ producing a substance with a specific action was made by Zirm (1956a, b; 1957), but the results he gives were criticised by Langer - Schierer \& Langer (1957) who maintained the view that the effects obtained can be perfectly well explained by the storage function of BAT.

\section{MATERIAL AND METHODS}

The material on which work for this study was carried out was taken from the collections in the Mammals Research Institute of the Polish Academy of Sciences at Białowieża. The animals were caught during the period from $1953-1956$ by means of metal cylinders. A description of the biotopes and structure of the trapping areas are given by Borowski \& Dehnel (1952). A total number of 3322 individuals of Sorex araneus Lin na e s, 1758, were used in the investigations.

The material from the different years (Table 1) is not uniform from the aspect of numbers. 1955 is represented most numerously, as are the young in 1953 and 1954 . The small number of specimens in 1956 is due to the difficulties in catching a suitable number of animals. The very small numbers of old adults in the autumn the period when shrews die naturally - are self-explanatory and data from this period can be treated as given for information only.

$B A T$ was prepared from material previously fixed in methyl alcohol (about $85 \%$ ). The situation of $B A T$ in $S$, araneus is given by Gras é (1955) after A $\mathrm{rn} \mathrm{b}$ ä ckChristie - Linde (1907). In the specimens which we dissected it was also found in a similar situation, in the scapular region, distributed symmetrically on hoth sides of the spine. The main mass of the tissue more or less covers the thoracic section (from the cervical vertebrates in a caudal direction). Flatter lobes of BAT extend from it on to the sides, reaching to the armpits.

$B A T$ was removed after incising the skin on the back, removing the connective tissue, and cutting through two narrow bands of muscle. The prepared tissue was kept in $85 \%$ methyl alcohol. Before weighing it was transferred for 24 hours to distilled water, changed twice (in order to avoid too rapid evaporation during weighing). The material was dried on cellulose sheets immediately before weighing, which was made with accuracy up to $0.1 \mathrm{mg}$. 
The estimated losses in weight of the tissue caused by washing out the lipids were more or less constant in the material owing to the use of uniform methods of fixing and preserving the animals. The weights obtained for $B A T$ may therefore be considered as reflecting the actual changes taking place during the seasons of the year.

In cases in which the body weight of single individuals or the weight of the brown adipose tissue, or the value of the calculated ratio of the weight of this tissue to the body weight differed from the remainder by more than one class divis . ion, then these data were not included in the calculations of the mean, but were marked in the respective place on the figure or table.

The $\mathrm{t} \mathrm{S} \mathrm{t}$ udent test was used in the statistical calculations.

Table 1.

Material examined.

\begin{tabular}{|c|c|c|c|c|c|c|c|c|c|c|c|}
\hline \multirow{3}{*}{$\begin{array}{c}\text { Age } \\
\text { group }\end{array}$} & \multirow{3}{*}{ Months } & \multicolumn{8}{|c|}{$\begin{array}{llllll}Y & e & a & & & s\end{array}$} & \multirow{2}{*}{\multicolumn{2}{|c|}{ Total }} \\
\hline & & \multicolumn{2}{|c|}{1953} & \multicolumn{2}{|c|}{1954} & \multicolumn{2}{|c|}{1955} & \multicolumn{2}{|c|}{1956} & & \\
\hline & & 99 & 88 & 99 & 86 & $q q$ & 66 & $q q$ & $80^{\circ}$ & १९ & ofd \\
\hline \multirow{11}{*}{ 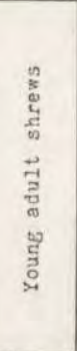 } & v & 9 & 3 & & & & & & & 9 & 3 \\
\hline & VI & 85 & 107 & 59 & 58 & 103 & 94 & 3 & 5 & 250 & 264 \\
\hline & VII & 69 & 58 & 133 & 91 & 103 & 94 & 9 & 11 & 314 & 254 \\
\hline & VIII & 38 & 49 & 105 & 80 & 66 & 72 & 24 & 24 & 233 & 225 \\
\hline & IX & 47 & 51 & 51 & 61 & 115 & 125 & 18 & 10 & 231 & 247 \\
\hline & $\mathrm{x}$ & 7 & 6 & 11 & 17 & 20 & 10 & 8 & 6 & 46 & 39 \\
\hline & $X I$ & 2 & 2 & 2 & 12 & 60 & 44 & 2 & 1 & 66 & 59 \\
\hline & $x \perp 1$ & & & 6 & 12 & 3 & 2 & 6 & 5 & 15 & 19 \\
\hline & I & & & & & 9 & 7 & 20 & 26 & 29 & 33 \\
\hline & II & & & & & 9 & 7 & 1 & 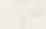 & 10 & 7 \\
\hline & III & 2 & 1 & 3 & & 11 & 13 & 15 & 8 & 31 & 22 \\
\hline \multirow{9}{*}{ 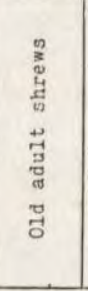 } & IV & 2 & 11 & 29 & 52 & 9 & 17 & 17 & 24 & 57 & 104 \\
\hline & v & 2 & 8 & 3 & 13 & 2 & 4 & 1 & & 8 & 25 \\
\hline & VI & 3 & 56 & 7 & 62 & 14 & 57 & 3 & 13 & 27 & 188 \\
\hline & VII & 6 & 17 & 14 & 35 & 19 & 29 & 1 & 8 & 40 & 89 \\
\hline & VIII & 21 & 34 & 19 & 43 & 22 & 12 & 1 & 1 & 63 & 90 \\
\hline & $1 \mathrm{X}$ & 28 & 16 & 29 & 31 & 51 & 19 & & 2 & 108 & 68 \\
\hline & $\mathrm{x}$ & 2 & & 18 & 7 & 4 & 5 & 1 & 2 & 25 & 14 \\
\hline & XI & 1 & 1 & 1 & & 2 & 2 & & 2 & 4. & 5 \\
\hline & XII & & & 1 & & & & & & 1 & \\
\hline \multicolumn{2}{|c|}{ Total } & 324 & 420 & 491 & 574 & 622 & 613 & 130 & 148 & 1567 & 1755 \\
\hline
\end{tabular}

III. SEASONAL VARIATION IN THE WEIGHT OF BROWN ADIPOSE TISSUE

The range of variation in the weight of fixed brown adipose tissue is considerable and fluctuates in principle between limits of 10 to $200 \mathrm{mg}$ (Table 2, Fig. 1). Weights for BAT higher than $200 \mathrm{mg}$ occur in about $0.5 \%$ of the specimens (in seven young females and nine old adults 3 females and 6 males). A very small number of specimens exceeded the limits of $250 \mathrm{mg}$ - these were: two young females from April 1954 (314.3 $\mathrm{mg}$ and $357.4 \mathrm{mg}$ ), one young male from June 1955 (343.8 mg), one 
Table 2.

Variation in the weight of brown adipose tissue in females and males of $S$. araneus during the period 1953-1956.

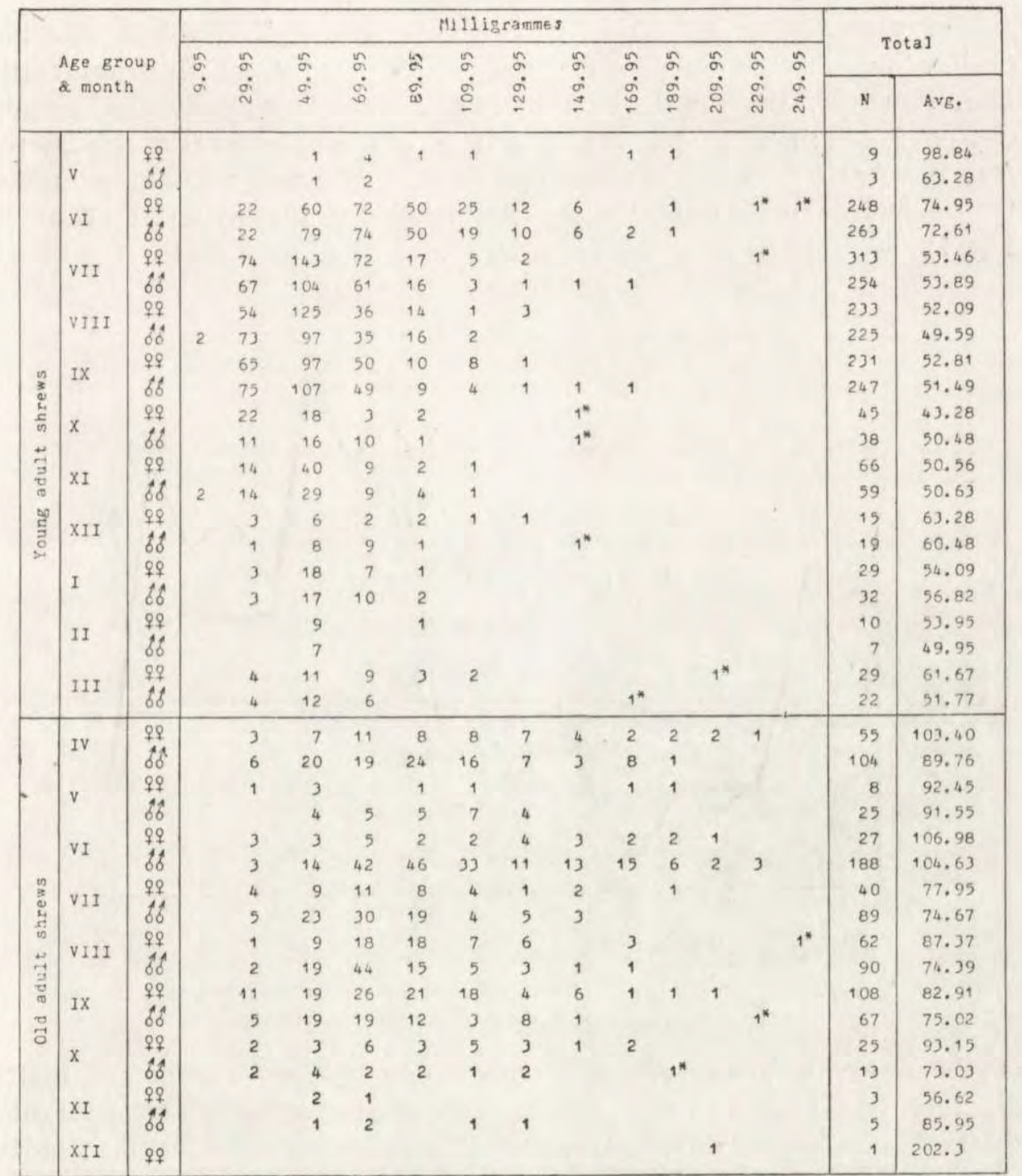

* Not included in calculation of the mean value for the whole material.

old adult female from November $1955(317.4 \mathrm{mg})$. These individuals were not included in the tables or figures.

The majority of weights of $B A T$ come within limits of $20-60 \mathrm{mg}$. During the period from June to December from $85-86 \%$ of the young individuals come within these limits, and in January and February as many as about $94 \%$. During the period of the spring jump in growth (when the 
weight of $B A T$ increases) the figure falls to $53 \%$ of the shrews, and firally $50 \%$ of the adult shrews (which have lived through winter) have weights of $B A T$ within these limits.

The course taken by variations in the weight of $B A T$ during the lif: cycle of the shrew exhibits differences in different years. In general outline, however, the appearance of its curves is similar, and certain characteristic moments are repeated in consecutive years (Fig. 2). Therefore before we pass to a discussion of successive years we shall consider the variations in BAT jointly for the whole of the material (Table 2, Fig. 1).

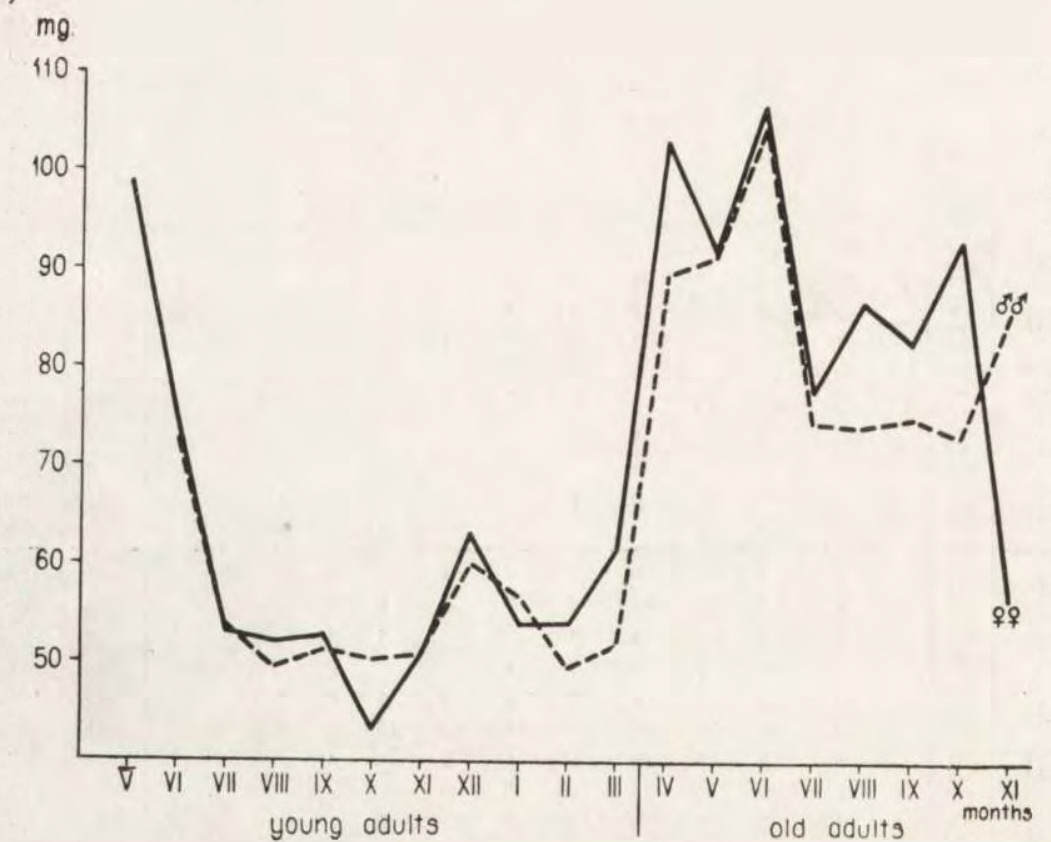

Fig. 1. Variation in the weight of brown adipose tissue in females and males of $S$. araneus during the period 1953-1956.

Differences in the curves of variations in old adult females and males are undisputed ones. In the case of young shrews, although the majority of the sexually immature individuals $(\mathrm{P} \mathrm{u} c \mathrm{ek}, 1960)$ should form fairly uniform material, these differences are apparent. During the period from June to September the differences between curves of variations in the weight of $B A T$ in young females and males are on the borderline of significance (when $\mathrm{P}_{0.05}$ they are significant, when $\mathrm{P}_{0.01}$, non-significant). The longer sections of these curves considered (from June to February) exhibit statistically significant differences when $\mathrm{P}_{0.01}$. It is therefore desirable to discuss variations in the weight of $B A T$ separately for females and males, 


\section{Females}

The highest weights of BAT in young females are observed in June, to be exact, during the first ten days of June. This is BAT in animals which have not spent more than two weeks of independent life outside the nest, while the females from the end of May (1953) which have only just left the nest have even greater mean weights of BAT (Table 2). This would form evidence of the relatively considerable weight of $B A T$ in the youngest shrews.

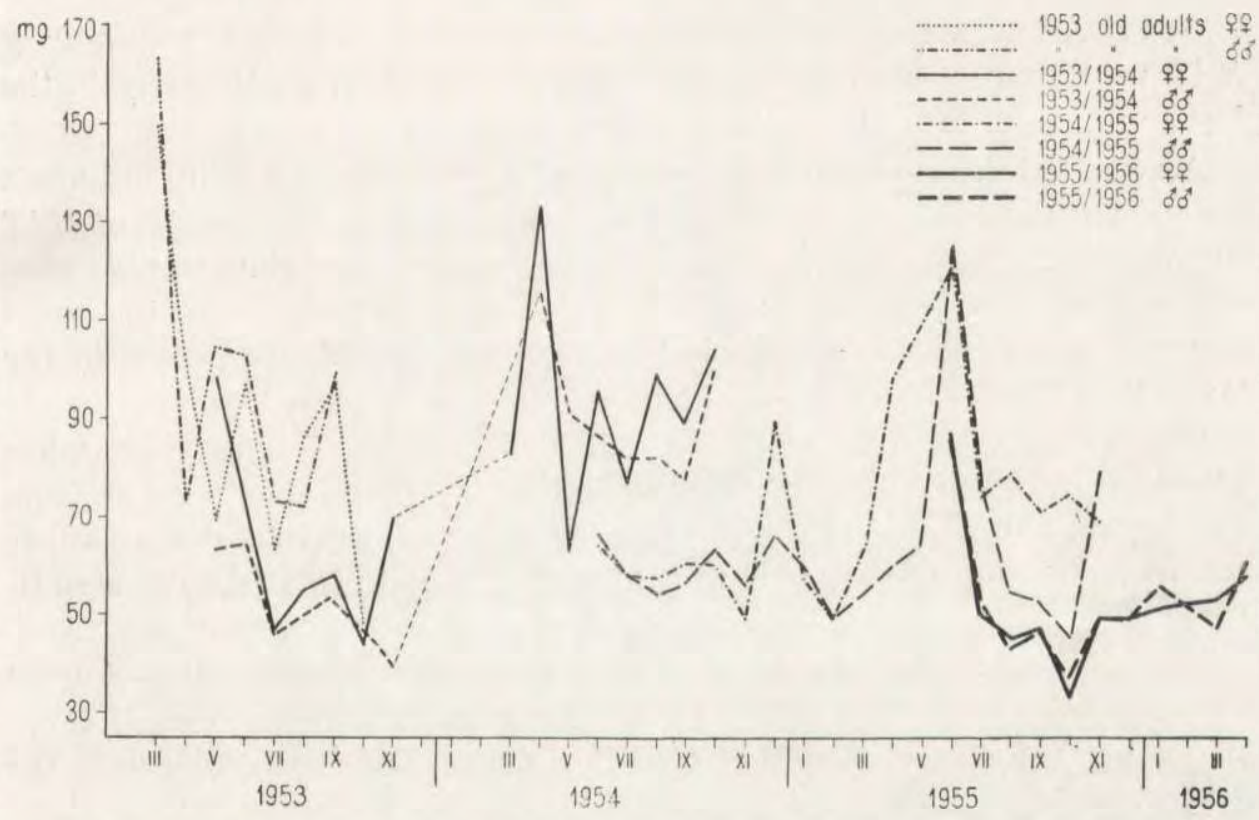

Fig. 2. Variation in the weight of brown adipose tissue in females and males of $S$. araneus during the period 1953-1956. Distribution in years.

As from the second ten-day period in June the weight of BAT decreases and its lowest values are to be found in the first $(1953,1954)$ or second $(1955,1956)$ ten days of July. The decrease in the weight of $B A T$ from June to July for the monthly means is about $29 \%$ and is statistically significant.

The weight of BAT, after a period of some stabilisation (July-September) decreases significantly in October, then increases up to December inclusive. $B A T$ increases in weight in the monthly means from October to December by $46 \%$ (statistically significant)

From December another decrease in the weight of BAT is observed, which reaches its lowest point in February. This decrease (in monthly means) of $14.7 \%$ is not, however, statistically significant. 
The increase in the weight of $B A T$ begins as from the last ten days of March and attains, in the great majority of individuals, considerable proportions in April. In extreme absolute values it reaches, e.g. in females from 1954, as much as $357.4 \mathrm{mg}$ : in females from 1955 up to $206.0 \mathrm{mg}$. $B A T$ weighing as much as this (in particular this applies to data from 1954 ) is only sporadically encountered in material from later months. The increase in the weight of BAT from February to April, in monthly means. is about $92 \%$ in relation to the mean value for February, this being statistically significant.

After the period of intensive increase in March-April the weight of $B A T$ in old adult females begins to decrease in May, particularly in the last ten days of May, the value is again a low one.

A repeated increase in the weight of $B A T$ is observed in old adult females in the first days of June. The fluctuations in the weight of $B A T$ during the periods April-May and May-June are statistically non-significant. It is possible that this is to some extent due to the small number of specimens $(n=8)$, but in any case the May decrease in the weight of $B A T$ (Fig. 1) should be interpreted with great care.

In July, as in the case of young animals, a considerable decrease takes place in the weight of BAT. The weight of the tissue decreases as from the second half of June $(1953,1954)$. The decrease, calculated in monthly means in relation to the mean for June, is $27 \%$ and is statistically significant.

Fluctuations in the weight of BAT during the periods July-August and August-September (Fig. 1) are statistically non-significant. Comparison of the mean weights of $B A T$ for August and September with the weight for June will reveal the reality of the variations taking place. The difference in the weights for June-August is on the borderline of significance (significant when $\mathrm{P}_{0.05}$, non-significant when $\mathrm{P}_{0.01}$ ), the JuneSeptember difference is statistically significant.

The mean weight of BAT increases in October. In the material from the late autumn, i.e. November, there are only three females about which no conclusions can be drawn.

\section{Males}

The course taken by variations in $B A T$ in young males is fairly similar to that described above for females. The highest mean weight of $B A T$ (Fig. 1) is observed in June - during the first (1953) or not until the second period of ten days $(1954,1955)$.

The decrease in the weight of BAT in July is about $26 \%$ in monthly means and, as in the case of the females, is statistically significant. 
From July to November, contrary to that in the females, the weight of $B A T$ in males does not exhibit any significant variations. It was found that the difference of $7.20 \mathrm{mg}$ (about $14 \%$ ) occurring between mean values of the weight of $B A T$ in males and females in October is not statistically significant.

During the period from November-December the weight of BAT increases. An increase in weight with mean values of about $16 \%$ is on the borderline of significance (difference significant when $\mathrm{P}_{0.05}$, non-significant when $\mathrm{P}_{0.01}$ ). It must be added here that the respective numbers of specimens were: in November - 59, in December -19 specimens. The mean weight of BAT in December is lower and its decrease in January is not as considerable as that in females. It is not until February that the value for the weight of $B A T$, with a difference in monthly means of $17 \%$ in relation to the mean from December (statistically non-significant), is lower than the value for females.

In old adults a slight increase in the weight of $B A T$ takes place as from the last ten days of March, but even so it is constantly lower than that in females. In April the weight of BAT rises sharply, the increase in relation to the mean value for February being $79 \%$. The weight of $B A T$ in males continues to rise up to June, with a very slight inhibition in this process in May, the increase in weight, in mean figures, from February to June (with $\mathrm{n}$ in February $=7$ and in June $=188$ ) being about $109 \%$.

The July decrease in the weight of BAT is marked in males also. As in the case of females, the difference in monthly means between the weight of $B A T$ in June and July is statistically significant.

From July to October the weight of $B A T$ is maintained at an almost unvarying level. In the case of the very few old adults $(n=5)$ from November, the amount of material is too scanty to permit of interpreting variation. Thus the course taken by variation in the weight of BAT in old adult males is characterised by, properly speaking, one peak only in June, coinciding with attainment of complete sexual maturity, followed by maintenance of a fairly even weight from July until the end of the animals' life.

In the whole of the materiai the weight of $B A T$ in males from February to November remains constantly at a lower level than that in females.

During the spring jump in growth the females react more rapidly and strongly than males. In mean values, the differences in the weight of BAT between them are: in March 19\%, in April 15\% and in May only about $1 \%$, in favour of the females, while the increase itself in the weight of $B A T$ begins later in males than in females. 
3. Differences in the Course Taken by Curves of the Weight of BAT in Shrews from Different Years

a. Young animals

The differences between curves of variations in the weight of BAT in different years in young males and females are illustrated by Fig. 3 .

Statistical treatment of the differences is given in table 3 .

The results obtained point to the fact that despite the general approximate similarity of the picture of variation in the weight of BAT in young shrews - differences occur between different years which may be statistically significant. Material is divided into two groups: one years 1953,1954 , the other $-1955,1956$, within the weight of $B A T$ is similar. These differences refer to successive years and would seem to depend on variations in the general condition of animals.
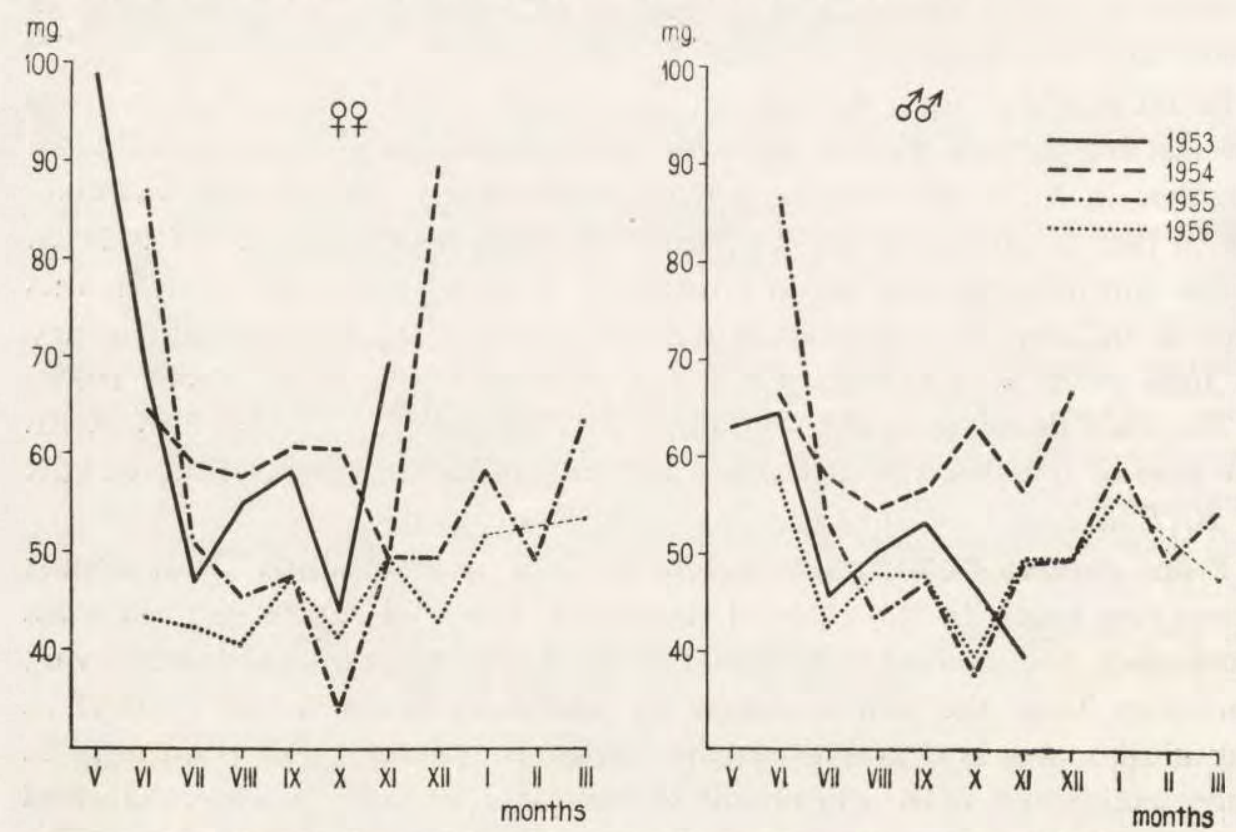

Fig. 3. Variation in the weight of brown adipose tissue in young adult females and males of $S$. araneus during the period 1953-1956.

Differences in the course taken by variations in the weight of $B A T$ also occur, as was mentioned earlier, between males and females from the same year. In the case of young shrews this is distributed as follows: in 1953 (June-October) the difference is significant; in 1954 (JuneDecember) non-significant or on the borderline of significance (significant when $\mathrm{P}_{0.05}$, non-significant when $\mathrm{P}_{0.01}$ ), when sections of the curves with larger numbers of individuals (June-October) were analysed. In 
1955 also this difference is on the borderline of significance. Analysis was not made of material from 1956 on account of the very small numbers of animals obtained.

\section{b. Old adults}

Since the number of old adult females in different months was not infrequently too small for the purpose, calculation was not made of the significance of differences in the curves of weight of $B A T$ in consecutive years. We should, however, like to emphasise certain differences here. Presumably differences in the degree of increase or decrease in the weight of BAT at certain times in the shrews' life are connected with the general condition of the animals. For instance, during the period of the spring jump in growth the increase in the weight of BAT from February to April is - for 1955 - about 97\%, for 1954 (from March to April) about $60 \%$ and in 1956 (also from March to April) only $7.8 \%$. Similarly, the July decrease in the weight of $B A T$ varies in consecutive years within limits from $6.0 \%$ (1954) to $38.9 \%$ (1955) (Fig. 2).

\section{Table 3.}

Differences between curves of variation in the weight of brown adipose tissue in young females and males during the period 1953-1956.

\begin{tabular}{|c|c|c|c|c|c|}
\hline \multicolumn{3}{|c|}{ e $\mathrm{m}$ a 1 e $\mathrm{s}$} & \multicolumn{3}{|c|}{$M$ a 1 e $s$} \\
\hline Period & Years & Difference & Period & Years & Difference \\
\hline$V I-X I$ & $1953-1954$ & non-s1gnificant & $v_{1}-x$ & $1953-1954$ & non-s1gnif1cant \\
\hline$V I-I$ & $1955-1956$ & non-s1gnificant & $V I-I$ & $1955-1956$ & non-s1gniflcant \\
\hline$V I-X_{I I}$ & $1954-1955$ & $\begin{array}{l}\text { significant when } \\
\mathrm{P}_{0.05} \text {, noti-sign. } \\
\text { when } \mathrm{P}_{0.01}\end{array}$ & $V I-X I$ & $1954-1955$ & s1gniflcant \\
\hline $\mathrm{V}_{1}-\mathrm{XI}$ & $1953-1955$ & significant & VI $-x$ & $1953-1955$ & s1gniflcant \\
\hline
\end{tabular}

The August increase in the weight of $B A T$ in old adult females in relation to the mean value for July is - in $1953: 36 \%, 1954: 10 \%, 1955-$ only $6.6 \%$. When taking into consideration the values for the weight of $B A T$ from the first ten days of August (where these values are the highest) its increase rises accordingly and in 1953 is $46,6 \%, 1954: 25.0 \%$ and 1955 (July - last ten days of August) - 18.8\%. Apart from 1954 (in June $\mathrm{n}=7$ ) the weight of $B A T$ does not attain in June level in either of the two remaining years.

In 1953 we observe in females a sort of shift of the August increase in the weight of $B A T$ to September, and not only does it not decrease in September but actually rises by about $12 \%$ in relation to the mean value for August. The increase in weight continued to be maintained even after three individuals with extremely great weights of $B A T$ had been excluded from the September mean value. 
In old adult males certain differences take place between different years, even while the distribution described above is maintained (Section III - 2). These variations were not analysed statistically and they consist mainly in the shift in time of increases and decreases in the weight of $B A T$ (Fig. 2).

The value for the weight of $B A T$ in males in relation to the value for the weight of $B A T$ in females is different in different years also. In 1953, the weight of $B A T$ in males is higher in all months except August, in 1954, except for May and July, and in 1955 - except for June and July it is lower, than in females. The greatest differences between the mean weights of $B A T$ in old adult males and females are those in 1955, and are somewhat similar to those observed in 1954 (Fig. 2).

IV. RATIO OF THE WEIGHT OF BROWN ADIPOSE TISSUE TO BODY WEIGHT

The body weight used for calculating this relation was taken from animals which had not been fixed, while the weight of $B A T$ refers to fixed tissue. We have assumed that the losses in the weight of $B A T$ when

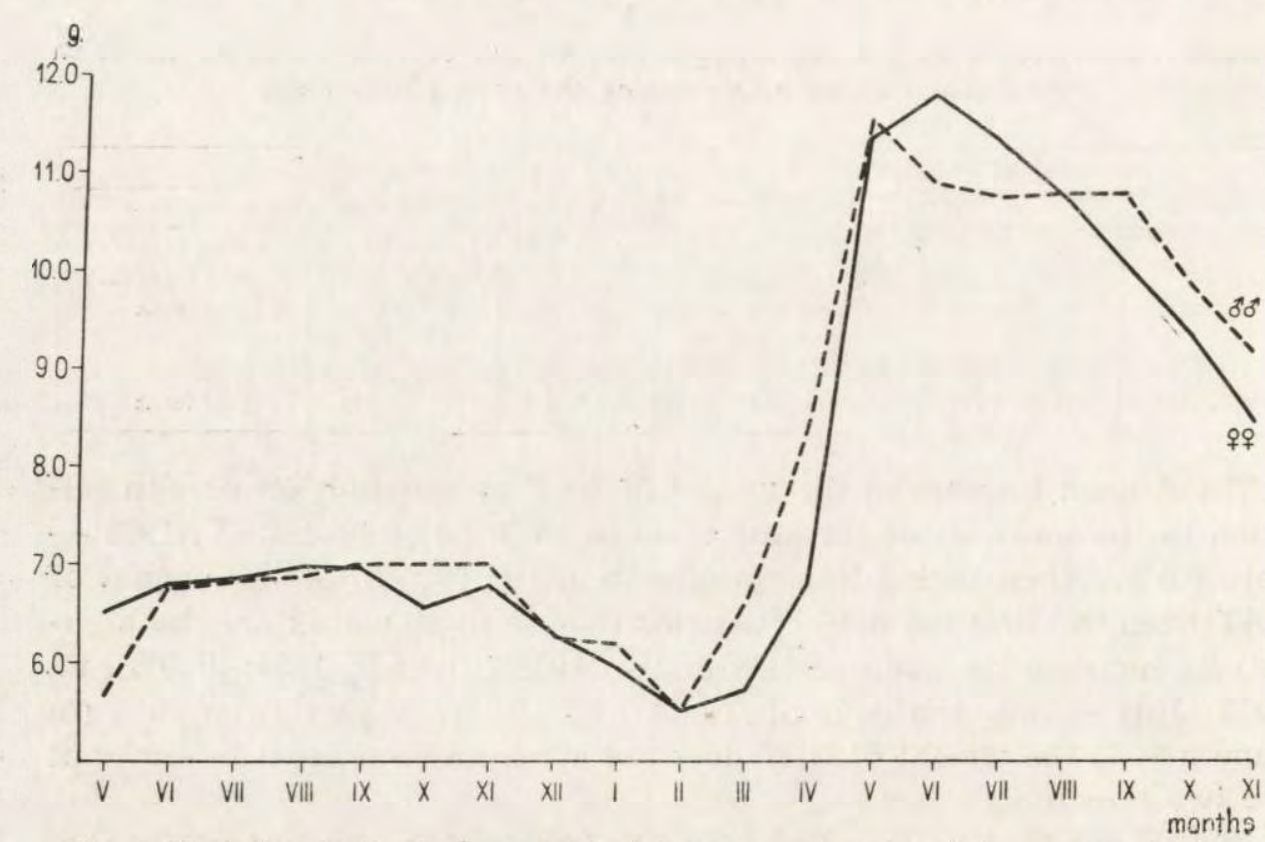

Fig. 4. Variation in the body weight of females and males of S. araneus during the period $1953-1956$.

the animals are fixed and preserved took place in a more or less constant way, which permits of the calculation and consideration of the relation of body weight and weight of $B A T$. 
Variation in the body weight of the shrew during the seasonal cycle have frequently been described (Dehne 1, 1949; B or ow sk i \& D e hne 1, 1952). Fig. 4 illustrates this point in our material.

Only slight differences in body weight in young shrews, and negligible ones in old adults, occur between consecutive years in the material we examined.

When comparing curves of variations in the body weight of young shrews (for the whole of the material) it was found that the difference between them is on the borderline of significance (significant when $\mathrm{P}_{0.05}$, non-significant when $\mathrm{P}_{0.01}$ ).

A considerable degree of dependence of the ratio of the weight of $B A T$ to body weight on the value for BAT is evident in young shrews. In July the body weight of young shrews does not decrease, but increases. The

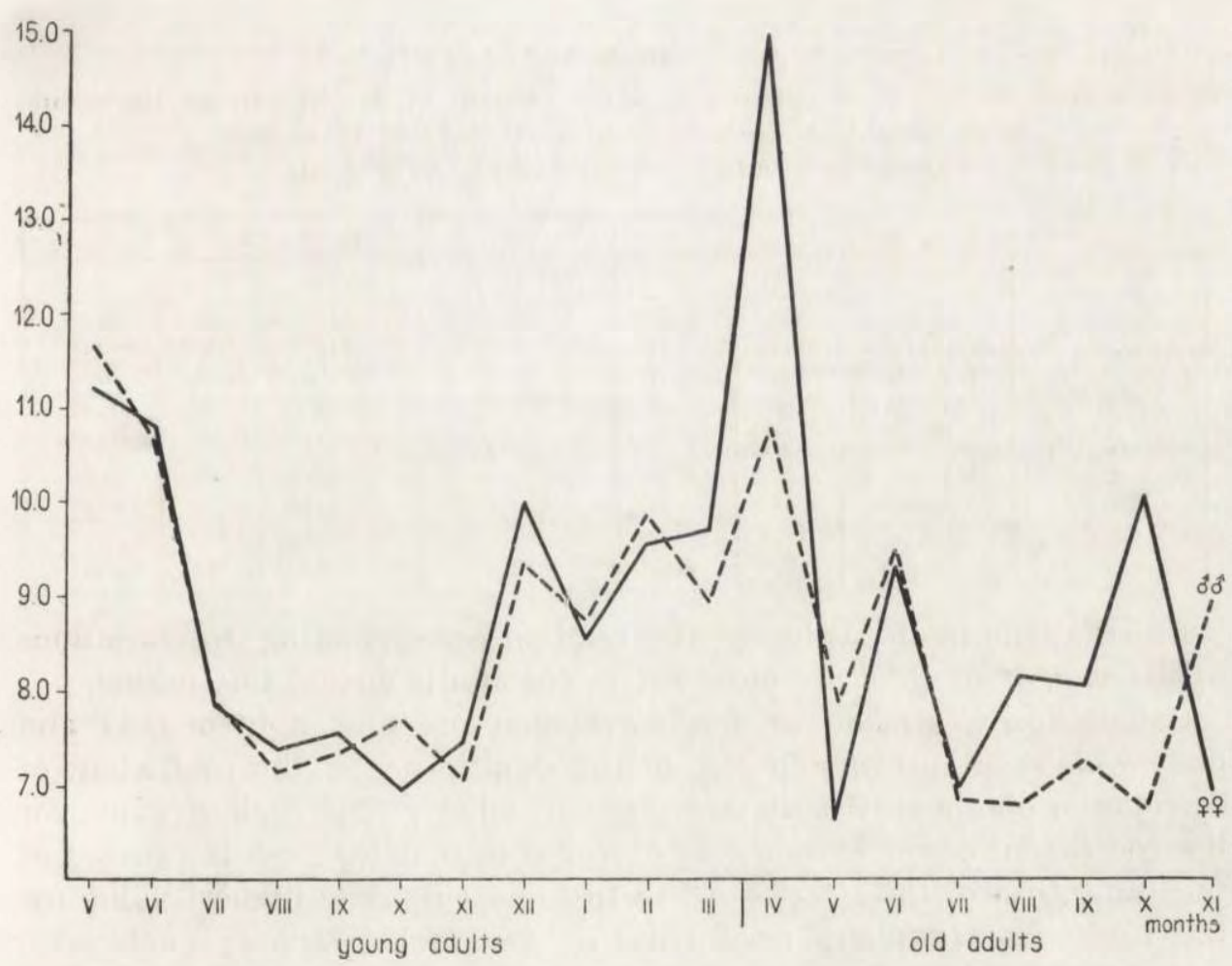

Fig. 5. Ratio of weight of brown adipose tissue (in $\mathrm{mg}$ ) to body weight (in g) in females and males of $S$. araneus during the period 1953-1956.

reduction in the weight of $B A T$ is considerable - the curve of the ratio of weight of tissue to body weight records this decrease. The case is similar in, for instance, October when the body weight and BAT- 
weight in males is maintained on the same level as that preceding this month - in the case of females it decreases (Figs. 1, 4, 5).

An interesting phenomenon takes place in the winter months. The ratio of the weight of $B A^{\prime} T$ to body weight increases markedly from November to December and is maintained at a relatively high level until February, far higher than during the summer and autumn (in December, for instance, it is only very slightly lower than in June). This is evidence of the considerable percentage of $B A T$ weight in the total body weight during the winter.

In March and April body weight increases in females more slowly and the weight of $B A T$ - faster. The ratio of both values to each other in females is higher than in males, this ratio having the highest value in the whole of the material, since in April a large number of females were noted as possessing the greatest weight encountered.

Table 4.

Value of the coefficient of correlation of the weight of brown adipose tissue and body weight in S. araneus during the period 1953-1956. (underlined values are statistically significant).

\begin{tabular}{|c|c|c|c|c|c|c|c|}
\hline & e $\mathrm{m} \quad \mathrm{a} \quad 1$ & s & & & $M$ a 1 e & & \\
\hline Age group & Months & $\mathrm{n}$ & $\boldsymbol{r}$ & Age group & Montbs & $\mathrm{n}$ & $r$ \\
\hline- & VI & 100 & 0.40 & \multirow{5}{*}{ Young adult } & VI & 100 & 0.27 \\
\hline \multirow{4}{*}{ Young adult } & VII & 100 & 0.33 & & VII & 100 & $\overline{0.41}$ \\
\hline & VIII - IX & 100 & 0.27 & & $V I I I-X I$ & 100 & $\overline{0.34}$ \\
\hline & $X I-X I I$ & 81 & 0.38 & & XII & 19 & $-\overline{0.39}$ \\
\hline & $I$ - II & 38 & 0.10 & & $I-I I$ & 38 & 0.55 \\
\hline \multirow{4}{*}{ 01d adult } & $I I I$ - IV & 85 & $\underline{0.68}$ & \multirow{4}{*}{ Old adult } & III - IV & 125 & 0.48 \\
\hline & VIII & 61 & $\overline{0.34}$ & & $V-V I$ & 100 & 0.42 \\
\hline & IX & 108 & 0.38 & & $V I I-I X$ & 100 & 0.30 \\
\hline & $x$ & 25 & $\overline{0.05}$ & & $\mathrm{x}$ & 13 & $-\overline{0.40}$ \\
\hline
\end{tabular}

Fluctuations in the value of the relation corresponding to variations in the weight of $B A T$ are observed in old adults during this period.

Calculation was made of the correlation of the weight of $B A T$ and body weight of shrews and also of the significance of the coefficient of correlation obtained. Results are given in table 4 . The highest value for the coefficient of correlation was observed in females from the period of the jump in growth (March-April) in the spring. The highest value for the coefficient in males occurs during the period January-February, while females do not, practically speaking exhibit any correlation at this time.

In young females the coefficient of correlations decreases from June to September, again reaching higher values in November-December. In young males at this time the coefficient of correlation in principle rises, being highest in July. 
No correlation between the weight of BAT and body weight is observed in old adult females during the period from May to August, and in October.

In males in two cases, in young shrews - in December and in old adults - in October the coefficient of correlation, despite its fairly high value, is non-significant. This may be due to the number of individuals being too small.

In the study by Borowski \& Dehnel (1952) these authors refer to the occurrence in the old adult material of "light" and "heavy" animals. This phenomenon may occur in both sexes, being more distinct in females. The authors connect it with reproduction (this concept was later criticised by Tarkow ski, 1955).

The connection between "heavy" and "light" body weights and the weight of BAT was traced in the material formed by old adult females from 1953-56. The females from different months were therefore split up into two weight groups: up to $10 \mathrm{~g}$ and exceeding $10 \mathrm{~g}$ (females weighing $10 \mathrm{~g}$ or very slightly over were allocated to the group of "heavy" females). The mean values for body weight and weight of BAT were calculated,

It is not possible to state, however, on the basis of the calculated mean values, that the "light" females have light $B A T$, and conversely, that "heavy" females have heavy BAT. In both groups of females there is a gradual constant decrease in body weight as from June to the end of the season.

It can only by stated here that the weight of $B A T$ would seem to depend to a certain extent on whether the shrew is fully sexually active or nearing the end of the breeding season. This is borne out by the gradual increase in the weight of BAT from July to October, with a simultaneous decrease in the percentage of females taking an active part in reproduction (pregnant, nursing). For instance, in June, in our material, the percentage of such females is $85.7 \%, 69.5 \%$ in September and only $37.5 \%$ in October.

\section{DISCUSSION}

As shown by the short review of literature given in the introduction, research on brown adipose tissue has been made from more or less all aspects, yet the question still remains open as to whether $B A T$ in animals which go into hibernation is the same as the $B A T$ in animals which do not hibernate. This tissue in $S$. araneus varies in a specific way unlike the variation in $B A T$ in the hedgehog (K a r o le w i c $z, 1953$ ).

In the case of young shrews the highest values of this weight are attained in the animals which have most probably only just left the 
nest - that is, the youngest. The great range of weight of $B A T$ in June and also its gradual decrease indicates, in our opinion, that during the first days of their independent life shrews are obliged to utilise this reserve to supplement their insufficient food supply. Possibly the reason for this insufficiency is their lack of experience in obtaining their own food. Laboratory observations of young shrews indicate that animals born in captivity had difficulty in obtaining food when they were supplied with larger insects (D e h n e 1, 1952).

Kisielewska (1963), on the basis of the studies made by $\mathrm{Tar}$ k ow s ki (1957) reached conclusions as to the reproduction of shrews by means of her own investigations of the infestation of shrews by parasites. The young shrews appearing in consecutive litters not as yet infected, in entering an existing population "dilute" it, as it were, causing a general

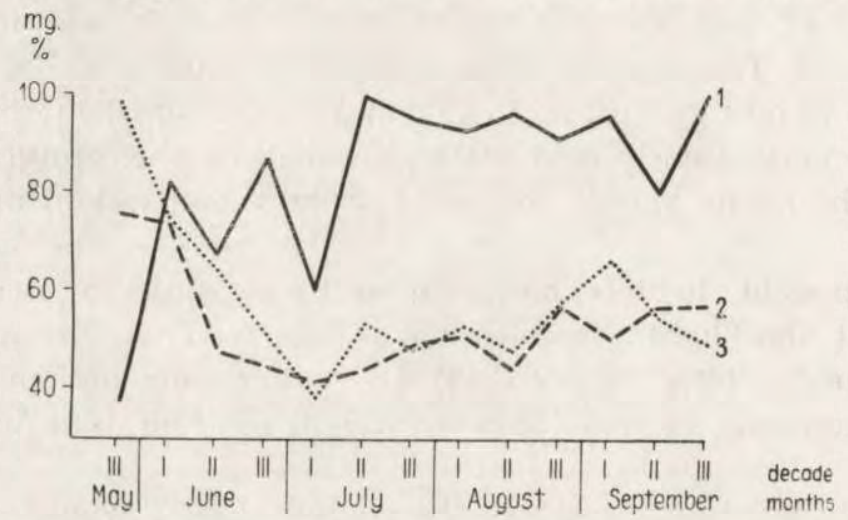

Fig. 6. Comparison of variation in the weight of brown adipose tissue and extensiveness of infestation of a population of young adult shrews in the summer months of 1953

1.- Extensiveness of infestation of a population of young adult shrews (after $\mathrm{K}$ isielewska, 1963), $2-B A T$-weight in young adult $\sigma^{\top} \sigma^{\top}, 3-B A T$-weight in young adult $q$ ㅇ.

decrease in the degree of infestation. This phenomenon is complicated by the possibility that the shrews might be infected while still in the nest, but in the material presented by K i s i e le w s k a (1963); it exhibits agreement with the previously calculated times of appearance of successive litters. If the young shrews do in fact have the highest weights of $B A T$ this should be regularly visible in the material. Two starting points necessary here: 1 . that the number of these individuals is sufficiently great for them to affect the mean value for a given period of ten days in a month and 2. that the females, despite continuation of reproduction, are able to supply the young from the subsequent litter material with suitably heavy $B A T$. This was traced on material formed by young shrews from 1953, 1954 and 1955. In 1953 (Fig. 6), with the exception of 
second litter, after which the weight of $B A T$ is already low, it decreases even more (but which may be connected with the short interval between first litter and second litter and the large number of older shrews from first litter), in all the remaining cases the weight of $B A T$ increases after the time at which a new litter was due to appear. The matter is slightly complicated in the case of females with their sixth litter, but we assumes that this is connected with the condition of the reproducing females. In 1954 and 1955 , in principle after the appearance of the theoretical litter, the weight of $B A T$ either increases or is maintained on the same level as therefore.

Simultaneously, as time passes, the weight of $B A T$ in young shrews decreases. Shrews from later months generally have lighter $B A T$ than the June shrews. It is possible that the females, being in poorer condition as the result of exhaustion due to simultaneous nursing of their young and a new consecutive pregnancy, are not in a condition to ensure that their young have as great a store of $B A T$ on leaving the nest as they had done in June. The percentage of pregnant females simultaneously nursing their previous litter is considerable and as, for instance, is shown by the study by Tarkowski (1957) based on shrew material from 1954, the figure for these females is $100 \%$ in May, $78 \%$ in June, $35 \%$ in July, $19 \%$ in August and $4 \%$ in September.

A very distinct phenomenon is the July depression in the weight of $B A T$, evident both in young and in old adult shrews. In all cases the decrease in the weight of $B A T$ is statistically significant. In the case of young shrews it is absolutely out of the question to explain this by the condition of the animals, since the body weight of these animals not only does not decrease in July, but even rises slightly (Fig. 4). It cannot be assumed that the decrease in $B A T$-weight precedes these changes since in the following month (August) the body weight in both sexes continues to increase. In old adult females in 1955 the body weight did in fact gradually but regularly decrease as from June, but in 1953 and 1954 it is in July (and in 1954 even in August) that it rises slightly. In old adult males, after the decrease in June, weight is maintained at an almost uniform level until September. This phenomenon should perhaps be explained in two ways. Brown adipose tissue exhibits a certain connection with the course taken by reproductive processes in shrews and with sex. First and foremost an increase in the weight of $B A T$ is observed in both sexes during the period of the jump in growth. In the case of females the weight of $B A T$ obtained is higher and proportionately greater than the increase in body weight. Possibly the July depression in the weight of the tissue in adult shrews is connected with reproduction. The weight of $B A T$ decreases after the main wave of reproduction is over. This would 
be the more probable since in old adult females the weight of $B A T$ exhibits fluctuations of a periodical character in the later months of the season, and its mean value increases constantly with the passage of time. This might form evidence of the possible influence of the appearance of successive litters on the condition of the animals and the weight of $B A T$, more plastic in this case, and possible more functionally connected (reserves of fat, glycogen etc.) than the weight of the whole body. An increase of this sort in the weight of BAT after a successive birth (caleulated theoretically) and successive emergence of the young shrews from the nest was observed in the material composed of females from 1953. In the late autumn this tendency to an increase in the weight of $B A T$ in non-reproducing individuals would clash with the tendency to decrease in the weight of $B A T$, which apparently occurs in old adults in a more exhausted condition towards the end of their life. In the case of old adult males - the sexually mature individuals, after a period of intensive reproduction and distinct decrease in the weight of $B A T$ during this period, exhibit almost no further variations. In the late autumn, at the end of the period of sexual activity, the weight of $B A T$ exhibits a tendency to increase in these animals also.

Under these circumstances the July depression in weight in young shrews would be directly connected with the exhaustion of this reserve for its living requirements and maintenance of condition and body weight on an appropriate level.

That the weight of BAT may be connected with sex is indicated by further facts. In young, sexually immature animals, the weight of $B A T$ behaves almost identically in the winter. In males during the period from July to December it exhibits almost no variation, that is, the course of variation is similar to that in old adult males during the period from July to October. In young females, amongst which a certain percentage of individuals may mature sexually during the first calendar year of life ( $\mathrm{Pucek}, 1960$ ), the course taken by variation is different. First of all the weight of $B A T$ in June, July and September is greater than that in males, and this is followed by a decrease in October, which is somewhat similar to the tendencies occuring in the material composed by old adult females. Possibly this weight, greater than that in males, and the autumn variation, should in fact be attributed to the possibility of sexual maturation.

There is one further aspect of the July variation. It may be assumed that the depressive variation in shrews beginning at the end of July could constitute in this case a factor acting in some way on the weight of $B A T$. In November and December the weight of BAT increases, and does not decrease until January and February, which would form evid- 
ence that the reserves of this tissue are used during the winter, but to an extent disproportionately low in comparison with its utilisation by animals which sleep through the winter. The whole course of the variation in BAT in shrews demonstrates the fact that this tissue has a totally different character from that in hibernating animals. It must be emphasised here that these is specific variation, not exhibiting close connections with the living conditions of shrews (e.g. the participation in the jump in growth in the early spring). Neither the late autumn increase nor the winter decrease are as intensive as those observed in hibernating animals. It would seem that brown adipose tissue in shrews should be regarded as a certain reserve (of fat, and possibly also of hormones and vitamins) which enables the animals to survive periods in their life cycle of particularly intensive metabolism (reproduction period) or unfavourable conditions (emergence from the nest etc.). It would also seem that the material available formed by old adult females is too small to make it possible to draw conclusions as to the behaviour of $B A T$ during the breeding season in animals only pregnant or only nursing, apart from finding connections of a general nature.

Coninx - Girardet (1927) in investigating BAT in Arctomys marmota $\mathrm{L}$. connects the intensive period of development of this tissue with involution of the thymus gland. B a $\mathrm{z}$ a $\mathrm{n}$ (1952) studied the thymus gland in $S$. araneus during the life cycle of these animals. She stated that "...the thymus gland has finished reduction or is in the final phases of this process, during the period of formation of the hibernating gland. In material formed by animals kept in captivity, on the other hand, I found that formation of the hibernating glands did not in any way affect the reduction of the thymus gland". It would of course be difficult to establish a close connection between the variations taking place in the thymus gland and in BAT during the life cycle, but it is also impossible to speak of the formation of $B A T$, since this tissue exists in shrews throughout their whole lives and all through this time is distinctly developed.

\section{CONCLUSIONS}

1. The weight of brown adipose tissue is subject to seasonal variations completely different from those observed in this tissue in animals which do hibernate.

The greatest weights of $B A T$ in young shrews are encountered in May and June immediately after the animals have left the nest. In July there is a decrease in the weight of $B A T$ in young and old adult shrews. The weight of $B A T$ in young males remains at an almost unvarying level from July to December and is lower (except for October) than that in females. In young females the weight of $B A T$ exhibits fluctuations in the late autumn.

No connection was established between the BAT-weight and pregnancy or nurs ing of young in old adult females. In old adult males the weight of $B A T$ does not 
exhibit any considerable fluctuations from July to October. In the autumn, as in the case of old adult females, tendencies to increase are observed.

2. Statistically significant sex differences were found in the variations in the weight of $B A T$ in young and in old adult shrews.

3. BAT participates in the spring jump in growth and the correlation of its weight with body weight is considerable during this period.

4. Curves of variations in the weight of $B A T$ in different years exhibit certain differences, which, in some cases are statistically significant.

5. The ratio of $B A T$-weight: body weight in young shrews and in old adults depends chiefly on the variations in the weight of $B A T$. The highest values of the coefficient of correlation of the weight of brown adipose tissue and body weight are observed in females during the period of the jump in growth and in young males in January and February $(r=0.55)$. There is a total absence of correlation in oid adult females in May, June, July and October, and in young females in January and February.

6. Variation in the weight of $B A T$ are to a certain degree parallel with the processes of sexual maturation and reproduction of shrews.

\section{REFERENCES}

1. $\AA$ rnbäck - Christie - Linde, A., 1907: Der Bau der Soriciden und ihre Beziehungen zu anderen Säugetieren. Ier T. (after G r a s s é, P i e r r e-P., 1955: Ordre des Insectivores: Anatomie et reproduction. Traité de zoologie, 17, 2: 1611, Paris).

2. B a z a n, I., 1952: Zmiany morfohistologiczne grasicy u Sorex araneus L. w cyklu życiowym. Ann. Univ. M. Curie-Skłodowska, C, 7, 5: 253-304, Lublin.

3. B ielak, T. \& Pucek, Z., 1960: Seasonal changes in the brain-weight of the common shrew (Sorex a, araneus L in $\mathrm{n}$ a $\in \mathrm{us}$, 1758). Acta theriol., 3, 13: 297300, Białowieża.

4. Boerner - Patzelt, D., 1957: Das braune Fett der sogenannten Winterschlafdrüse des Igels. Ztschr. mikr. anat. Forsch., 63: 5-34, Leipzig.

5. Borowski, S. \& De hne 1, A., 1952: Materiały do biologii Soricidae. Ann. Univ. M. Curie-Skłodowska, C, 7, 6: 305-448, Lublin.

6. B u cha lczy k, A., 1961: Variation in weight of the internal organs of Sorex araneus Linnae us, 1758. I. Salivary glands. Acta theriol., 5, 16: 229-252, Białowieża.

7. C a b о ṅ, K., 1956: Untersuchungen über die saisonale Veränderlichkeit des Gehirnes bei der kleinen Spitzmaus (Sorex minutus minutus L.). Ann. Univ. M. Curie-Skłodowska, C, 10, 5: 93-115, Lublin.

8. Coninx - Girardet, B., 1927: Beiträge zur Kenntnis innersekretorischer Organe des Murmeltieres (Arctomys marmota L.) und ihrer Beziehungen zum Problem des Winterschlafes. Acta zool., 8: 162-224, Stockholm.

9. Crowcroft, P. \& Ingles, J. M., 1959: Seasonal changes in the brain-case of the Common shrew (Sorex araneus L.). Nature, 183, 4665: 307-908, London.

10. De hne 1, A., 1949: Badania nad rodzajem Sorex L. Ann. Univ. M. Curie-Skłodowska, C, 4, 2: 17-102, Lublin.

11. De hne 1, A., 1952: Biologia rozmnażania ryjówki $S$. araneus L. w warunkach laboratoryjnych. Ibidem C, 6, 11: 360-376, Lublin.

12. Dzierżykraj - Rogalska, I., 1952: Zmiany histomorfologiczne tarczycy Sorex a, araneus L, w cyklu życiowym. Ibidem, C, 7, 4: 213-252, Lublin. 
13. Dzi erźykraj- R o g a lska, I., 1956: Die Veränderlichkeit der Parathyreoidea des Sorex araneus L. in seinem Lebenszyklus. Ibidem, C, 9, 3: 139-162, Lublin.

14. F a w cett, D. W., 1952: A comparison of the histological organisation and cytochemical reactions of brown and white adipose tissues. J. Morphol., 90, 2: $363-406$.

15. J o h a n s s o n, B., 1959: Brown fat: a review. Metabolism clin. and exp., 8, 3: 221-240. New York.

16. K a l a b u khov, N. I., 1956: Spiačka životnyh. Izd. Chark. Univ., 1-267, Charkov.

17 Ka rolewicz, L., 1953: The brown fat tissue of a hedgehog, Folia morph., 4: 49-58, Warszawa.

18. K a y se r, Ch., 1961: The physiology of natural hibernation. 1-325, Pergamon Press, Paris.

19. Kis ie lews k a, K., 1963: Food composition and reproduction of Sorex araneus Linna e us, 1758 in the light of parasitological research. Acta theriol., 7, 9: 127-153, Białowieża.

20. Langer - S chierer von H. \& Langer, H., 1957: Zur Frage der Funktion des brauen Fettgewebes bei winterschlafenden Säugetieren (Bemerkungen zu Arbeiten von Zirm). Z Naturforschg., 12 b: 587-589.

21. Menschik, Z., 1953: Histochemical comparison of brown and white adipose tissue on guinea pigs. Anat. Rec., 116, 4: 439-457.

22. Ptak, W., 1963: Chromatographic assay of steroid hormones present in the brown adipose tissue of mice and syrian hamsters. Folia biol., 11, 3: 347-352, Warszawa.

23. Pucek, Z., 1956: Untersuchungen über die Veränderlichkeit des Schädels im Lebenszyklus von Sorex araneus araneus L. Ann. Univ. M. Curie-Skłodowska, C, 9, 4: 163-211, Lublin.

24. P u cek, Z., 1957: Histomorphologische Untersuchungen über die Winterdepression des Schädels bei Sorex L. und Neomys Kaup. Ibidem, C, 10, 15: 399-428, Lublin.

25. Pucek, Z., 1960: Sexual maturation and variability of the reproductive system in young shrews (Sorex L.) in the first calendar year of life. Acta theriol., 3, 12: 369-396, Białowieża.

26. Pucek, Z., 1963: Seasonal changes in the brain-cases of some representatives of the genus Sorex from the Palearctic. J. Mammal., 44, 4: 523-536.

27. Ratsimamanga, A. R., Costes - Sodigné, G. \& Nigeon - Dure u il, M., 1958: Le comportement du rat surrénaloprive soumis au froid en fonction de sa graisse interscapulaire. C. R. Soc. Biol., 152, 6: 950-960, Paris. *

28. S chubarth, H., 1958: Zur Variabilität von Sorex araneus araneus L. Acta theriol., 2, 9: 175-202, Białowieża.

29. S e 1 y e, H. \& T imira S, P. S., 1949: Participation of "brown fat" tissue in the alarm reaction. Nature, 164: 745-746.

30. S malle y, R. L. \& D r y e r, R. L., 1963: Brown fat: Thermogenic effect during arousal from hibernation in the bat. Science, 140, 3573: 1333-1334.

31. S mith, R. E. \& Hock, R. J., 1963: Brown fat: Thermogenic effector of arousal in hibernators. Science, 140, 3563: 199-200.

32. Suomalainen, P. \& Herlevi, A. M., 1951: The hibernating gland and the alarm reaction. Arch. Soc Zool. Bot, Fenn, "Venamo", 5, 2: 72-73. 
33. Ta r k ow ski, A. K., 19\$7: Badania nad rozrodem i śmiertelnością zarodkową u ryjówki aksamitnej (Sorex arancus L.). Cz. II. Rozród w warunkach naturalnych. Ann Univ. M. Curie-Skłodowska, C, 10, 8: 177-244, Lublin.

34 Wertheimer, E. \& Shapiro, B., 1948: The physiology of adipose tissue. Physiol Revs, 28, 4: 451-464.

35 Z i r m, von K. L., 1955a: Ein Beitrag zur Kenntnis der natürlichen Winterschlafes und seines regulierenden Wirkstoffes I. Z. Naturforschg., 11 b: $530-534$.

36. Z i r m, von K. L., 1956b: Ein Beitrag zur Kenntnis der natürlichen Winterschlafes und seines regulierenden Wirkstoffes II. Ibidem, $11 \mathrm{~b}: 535-538$.

37. Z i r m, von K. L., 1957: Ein Beitrag zur Kenntnis der natürlichen Winterschlafes und seines regulierenden Wirkstoffes III. Ibidem, 12 b: $589-593$.

Polish Academy of Sciences,

Mammals Research Institute,

Białowieża, Poland.

\section{STRESZCZENIE}

Przebadano zmienność sezonową i wiekową ciężaru tkanki tłuszczowej brunatnej (TTB) u 3322 osobników Sorex araneus Linna e us, 1758. Material (Tabela 1) pochodził $\mathrm{z}$ odłowów w Białowieskim Parku Narodowym, w latach 1953-1956. Analizowano ciężar TTB utrwalonej uprzednio w alkoholu metylowym (około $85 \%$ ), przyjmując, że strata na ciężarze w wyniku wypłukiwania lipidów z tkanki przy utrwalaniu i konserwowaniu ma charakter mniej więcej stały.

W wyniku badań stwierdzono, że:

W zmienności ciężaru TTB u ryjówek młodych i przezimków występują różnice plciowe statystycznie istotne.

Najwyższe ciężary TTB u ryjówek młodych spotyka się w maju i początkach czerwca, zaraz po opuszczeniu przez nie gniazda.

W lipcu, w calym materiale, następuje spadek ciężaru TTB (istotny statystycznie), związany wg przypuszczeń autorek - u młodych z utrzymaniem kondycji, $\mathrm{u}$ dorosłych przezimków $\mathrm{z}$ nasileniem rozrodu i wykorzystywaniem $\mathrm{w}$ obu przypadkach posiadanych rezerw (Tabela 2 , rycina 1,2 ).

Ciężar TTB u młodych samców pozostaje od lipca do grudria na prawie niezmienionym poziomie i jest niższy (za wyjątkiem października) niż u samic. U młodych samic, ogólnie wyższy ciężar TTB i jego zmiany jesienią - przypuszczalnie mogą wiązać się z możliwością dojrzewania pewnej ilości samic w pierwszym roku życia (Tab. 2, ryc. 1).

Ciężar TTB młodych wzrasta na zimę (XI, XII) a następnie w styczniu i lutym spada (Tab. 2, ryc. 1). Zmiany te są nieporównywalne w TTB, w tymże okresie, u zwierząt zasypiających na zimę (np. chomik).

Ciężar TTB wzrasta gwałtownie w czasie wiosennego skoku wzrostowego i jego korelacja $\mathrm{z}$ ciężarem ciała jest $\mathrm{w}$ tym okresie znaczna (Tabela 4). TTB samic reaguje znacznie silniej i szybiej niż samców, odwrotnie niż to obserwuje się w przypadku zmian ciężaru ciała (Ryc. 1, 4).

U samic przezimków ciężar TTB wykazuje wahania związane przypuszczalnie z rozrodem, przy czym nie stwierdzono zależności miẹdzy wartością ciężaru TTB a ciążą lub tylko karmieniem mlodych. Srednie miesięczne ciężaru TTB rosną w miarę postępu sezonu i zmniejszania się procentu samic aktywnych płciowo (Tab. 2, ryc. 1, 2). 
U samców przezimków od lipca do października ciężar TTБ nie wykazuje większych wahań. Jesienią, podobnie jak u samic przezimków, obserwuje się u niego tendencje do wzrastania (Tabela 2 , ryc. 1,2 ).

Na całym przebiegu zmienności ciężar TTB zachowuje się zupełnie swoiście i nie wykazuje bezpośredniej zależności od aktualnej kondycji zwierzęcia, mimo, że wydaje się podlegać ogólnym zmianom kondycyjnym (udział w skoku wzrostowym, spadek późną jesienią u części przezimków). Najwyższe wartości współczynnika korelacji ciężaru TTB i ciężaru ciała obserwuje się u samic w okresie skoku wzrostowego i u samców młodych w styczniu i lutym. Zupełny brak korelacji zaznacza się u samic przezimków w maju, czerwcu, lipcu i październiku i u młodych samic w styczniu i lutym (Tabela 4).

Krzywe zmienności ciężaru TTB w poszczególnych latach wykazują pewne różnice, które mimo zachowania w zasadzie jednakowego ogólnego schematu - mogą być istotne statystycznie (Tabela 3 , ryc. 2,3 )

Stosunek ciężaru TTB do ciężaru ciała u młodych ryjówek i u przezimkow kształtuje się głównie w zalewności od zmienności ciężaru TTB. Zimą ciężar TTB stanowi dość znaczny procent ciężaru ciała (Ryc. 5).

$\mathrm{Na}$ podstawie dokonywanych badań stwierdza się, że zmienność tkanki tluszczowej brunatnej u ryjówki aksamitnej różni się od zmienności tej tkanki u zwierząt zapadających w sen zimowy co wydaje sıę świadczyć o jej odmiennym charakterze i funkcji u ryjówek. 